\title{
TEXTO E IMAGEN EN LA ESTORIA DEL NOBLE VESPASIANO (SEVILLA, 1499): LA CURACIÓN DEL EMPERADOR*
}

\author{
Juan Manuel CACHo BlecuA \\ Universidad de Zaragoza \\ jmcacho@unizar.es
}

El 25 de agosto de 1499 Pedro Brun publicaba en Sevilla un librito de 36 hojas cuyo inicio refleja su posible título y sus ejes vertebradores, cada uno de los cuales tenía interés por sí mismo": "Aquí comiença la Istoria del noble Vespesiano, emperador de Roma, cómo ensalçó la fe de Jesucristo porque lo sanó de la lepra que él tenía, e del destruimiento de Jherusalem, e de la muerte de Pilatos» $(201)^{2}$. Sus principales hitos narrativos están adornados con 15 xilografías que ocupan toda la plana, cuya relación con su texto y su contexto constituirán el objeto de nuestro trabajo, en el que prestaremos es-

*Este trabajo se ha realizado en el marco del Proyecto de Investigación FFI2012-32259, concedido por el Ministerio de Economía y Competitividad. Se inscribe en el grupo investigador 'Clarisel', que cuenta con la participación económica tanto del Departamento de Ciencia, Tecnología y Universidad del Gobierno de Aragón como del Fondo Social Europeo.

${ }^{1}$ Loyal A. T. Gryting, «The Venjance Nostre Seigneur as a Mediaeval Composite», en The Modern Language Journal, 38:1 (1954), pp. 15-17 (15).

${ }^{2}$ Ha sido editado por R[aymond] Foulché-Delbosc, «Ystoria del noble Vespesiano», en Revue Hispanique, 21 (1909), pp. 567-634. Lo transcribió Cristina González para el Hispanic Seminary of Medieval Studies, Historia del noble Vespasiano (Sevilla 1499). London, British Library, G 10211, [En línea]. Enlace: $<$ https://textred.spanport.wisc.edu/chivalric/texts\%20bilingue.html $>$ [Consulta: 12/03/2016]. Reprodujo una edición semidiplomática José Barbosa Machado, História do mui Nobre Vespasiano Imperador de Roma, Paris, c. 1475, Toledo, c. 1492, Lisboa, 1496 y Sevilha, 1499, $5^{\text {a }}$ ed., Braga, Vercial, 2015. Para nuestras citas transcribimos el texto de la edición de 1499, puntuando, separando las palabras y acentuando de acuerdo con los criterios modernos. El signo tironiano lo resolvemos como $e$. Regularizamos grafías en los casos de $u$ con valor consonántico, $v, y$ con valor vocálico o semivocálico, $i$, y $q$ con valor de $c$. Para facilitar su localización remitimos entre paréntesis a la edición de David Hook, The Destruction of Jerusalem: Catalan and Castilian Texts, London, King's College London, Centre for Late Antique and Medieval Studies, 2000, referencia imprescindible para la fijación del texto y su interpretación. Para la bibliografía posterior, véase Karla Xiomara Luna Mariscal, «Bibliografía de las historias caballerescas breves (1995-2015)», en Tirant: Butlletí informatiu i bibliogràfic, 18 (2015), pp. 317-360 (359-360). 
pecial atención a los grabados relacionados con la curación del emperador. A nuestro juicio, las ilustraciones embellecen los episodios considerados más significativos; sus códigos visuales se complementan con los verbales a los que aluden, una multiplicidad sígnica a través de la cual accede el receptor a la obra y que potencia ciertos sentidos e interpretaciones, al tiempo que favorece su recuerdo.

El íncipit de la edición previa de [Toledo], [Juan Vázquez], [1491-1494] contiene mínimas variantes: «Aqui comiença la estoria del noble Vaspasiano» (201) ${ }^{3}$. Muy similar debía ser el de la versión portuguesa de Lisboa, Valentino de Moravia, 20 de abril de 1496, adornada con 27 grabados, pues, aunque no se ha conservado su comienzo, en su colofón figura «foy emprimida a presente estoria d(o) muy nobre Vespesiano emperador de Roma» ${ }^{4}$.

Los tres ejemplares, relacionados entre sí, reproducen una de las historias legendarias medievales de mayor éxito: «Di quante liggende sacre ebbe il medio evo la più celebre, la più diffusa è senza dubio [...] della vendetta di Cristo e della distruzione di Gerusalemme» ${ }^{5}$. Este último acontecimiento constituyó una referencia recordada por los cristianos desde el siglo IV gracias a la lectura de Lucas $(19,41-44)$, entre el noveno y el undécimo domingo después de Pentecostés, por lo general el décimo.

L'évangile qui annonçait cette destruction et qui n'était en fait qu'une prophétie ex eventu, devenait naturellement le thème du sermon dominical. Certains prédicateurs invitaient les fidèles à voir dans la destruction de Jérusalem le châtiment qui attend tout pécheur, reprenant ainsi l'interprétation de Grégoire le Grand, d'autres au contraire privilégiaient l'explication historique, suivant en cela Walafrid Strabon ${ }^{6}$.

El suceso fue profusamente recogido, y en muchas ocasiones ilustrado, en muy diversos textos y géneros: libros litúrgicos, exegéticos, de horas, biblias, sermones, literatura religiosa canónica, hagiografía, historiografía, especialmente la relacionada con Josefo, etc.; sobre todo se había difundido a través de la tradición apócrifa legendaria, una de las más influyentes en su articulación literaria. A fines del siglo XII con materiales de la Cura sanitatis

\footnotetext{
${ }^{3}$ Constituye el texto base de la edición de David Hook, The Destruction of Jerusalen: Catalan and Castilian Texts, por la que citamos.

${ }^{4}$ Estoria do muy nobre Vespesiano emperador de Roma (Lisbon, 1496), ed. de David Hook y Penny Newman, Exeter, University of Exeter, 1983, p. 67.

${ }^{5}$ Arturo Graf, Roma nella memoria e nelle immaginazioni del Medio Evo con un'appendice sulla leggenda di Gog e Magog, Torino, Giovanni Chiantore, 1923, p. 285.

${ }^{6}$ Denise Hillard, «La Destruction de Jérusalem en bande dessiné (Paris, vers 1515)», en Bulletin du Bibliophile, 2 (1996), pp. 302-340 (303).
} 
Tiberii, la Vindicta salvatoris y la Mors Pilati se había creado una «chanson de geste», La Venjance Nostre Seigneur ${ }^{7}$, que en sus transformaciones y prosificaciones posteriores es conocida de muy diferentes maneras: Vindicta Salvatoris, Vengeance de Nostre-Seigneur, Prise, Siege o Destruction de Jérusalem, etc.

Esta diversidad va unida a la multiplicidad de sus cauces genéricos y a la diversidad de sus tamaños. "Verse versions, prose versions, chansons de geste, mistery plays, book-length documents and one-page résumés, all attest to the widespread diffusion of the apocryphal Vengeance of Our Lord throughout the medieval Christian world ${ }^{8}$. Los casi cincuenta códices conservados de las nueve familias de la versión francesa en prosa reflejan su popularidad, revitalizada en el último cuarto del siglo XV, sobre todo en su última década, gracias a la imprenta. En esta época proliferaron discursos que favorecían su recepción: religiosos, apocalípticos, escatológicos, milenaristas, mesiánicos, antisemitas, propagandísticos o caballerescos, algunos unidos y potenciados en unos años en los que el temor al fin del mundo fue muy acusado9. La mayoría tenían un alcance internacional, si bien podían cobrar especiales resonancias en cada país.

El centro narrativo y punto de partida de la Estoria del noble Vespasiano lo constituye la destrucción de Jerusalén como venganza del pagano Vespasiano, quien así agradece haber sido curado de su lepra mediante el contacto con la Santa Faz impregnada en el paño de la Verónica. A estos dos hilos

\footnotetext{
${ }^{7}$ Según Loyal A. T. Gryting, art. cit., p. 16, «The chanson de geste stages of the Venjance Nostre Seigneur are available to us in nine widely scattered manuscripts, which represent five different stages in the legend, ranging in time from the twelfth century through the fifteenth, and in length from fewer than 1200 verses to over 3400».

${ }^{8}$ La Vengeance de Nostre-Seigneur. The Old and Middle French Prose Versions: the "Cura sanitatis Tiberii» («The Mission of Volusian»), the «Nathanis Judaei Legatio» ("Vindicta Salvatoris»), and the versions found in the "Bible en fraçais» of Roger d'Argenteuil or influenced by the Works of Flavius Josephus, Robert de Boron and Jacobus de Voragine, ed. de Alvin E. Ford, Toronto, Pontifical Institute of Mediaeval Studies, 1993, p. 1. Véase también La Vengeance de Nostre-Seigneur. The Old and Middle French Prose Versions: The Version of Japheth, ed. de Alvin E. Ford, Toronto, Pontifical Institute of Mediaeval Studies, 1984. Antes de la edición de los textos por Ford, Alexandre Micha trazó las principales pautas de su difusión en Francia, «La légende de l'empereur malade et de la Vengeance du Sauveur dans les récits en prose française», en Mélanges de littérature du Moyen âge au XXé siècle offerts à Mademoiselle Jeanne Lods, vol.1, Paris, 1978, pp. 433-446.

${ }^{9}$ Alain Milhou, Colomb et le messianisme hispanique, version française de Mayi Milhou-Binard revue par l'auteur, [Montpellier], Presses Universitaires de la Méditerranée, ETILAL, 2007, p. 281. Para el contexto hispano, añádase la introducción de Juan Luis Carriazo Rubio a la Historia de los hechos del marqués de Cádiz, Granada, Universidad de Granada, 2003, y sobre todo Pedro Cátedra, Juan Miguel Valero Moreno y Francisco Bautista, "Historias de la divinal victoria de Orán» por Martín de Herrera. Edición en facsímile de la impresa en su taller de Logroño por Arnao Guillén de Brocar en 1510, publicada en conmemoración del quinto centenario de la conquista de Orán (1509), 2 vols., San Millán de la Cogolla, Instituto Biblioteca Hispánica, Cilengua, 2009.
} 
superpuestos, debe añadirse el castigo de Pilatos, juzgado en Roma, si bien la ejecución de la sentencia se realiza en Alvana (Viana).

El estemma de D. Hook refleja las relaciones entre los primeros testimonios ibéricos, que se remontan a un antecedente catalán próximo, proveniente a su vez de un texto francés ${ }^{10}$ :

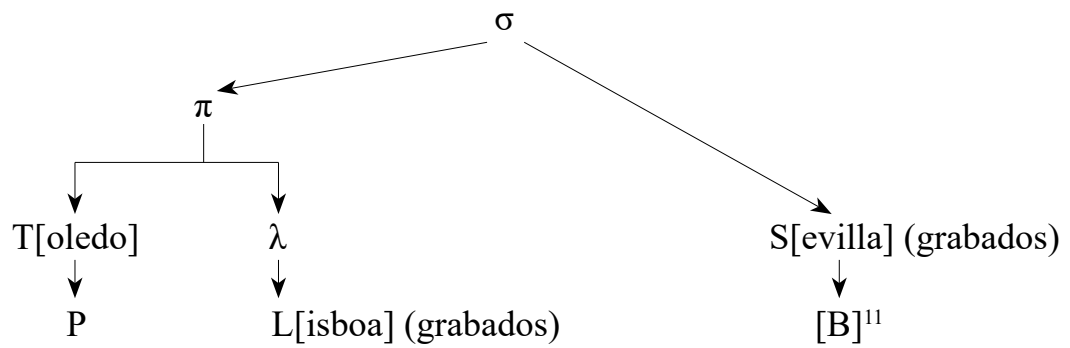

Desde una perspectiva iconográfica, si los grabados se hubieran transmitido de la misma manera que el texto, lo que no siempre es así porque pueden copiarse o imitarse de forma independiente, tanto el arquetipo $\sigma$ como $\pi$ y $\lambda$ estarían ilustrados con imágenes. Así se explicarían de forma coherente las similitudes y diferencias entre las estampas de Lisboa (1496) y de Sevilla (1499), que no son copia una de otra pero se remontarían a idénticos modelos, con independencia de su transmisión ${ }^{12}$ : ambas tienen un indudable aire de familia, al mismo tiempo que se diferencian en múltiples detalles, empezando por su tamaño.

\section{Los grabados del incunable sevillano}

Los impresores españoles editaban una obra de la que podían prever un cierto éxito, tanto por el contexto propicio hispano, como por haber alcanzado cierta popularidad en Europa, especialmente en Francia, como puede comprobarse en el Gesamtkatalog der Wiegendrucke (GW) y el Incunabula Short Title Catalogue (ISTC); ambos, con razón, unifican los títulos, en este caso bajo la denominación de Destruction de Jérusalem ${ }^{13}$.

${ }^{10}$ David Hook, «La transmisión textual de la Estoria del noble Vaspasiano», en Incipit, 3 (1983), pp. 129-172 (160), y The Destruction of Jerusalem: Catalan and Castilian Texts, ob. cit., p. 114

${ }^{11} \mathrm{P}$ corresponde a la copia manuscrita del siglo xVII, conservada en la Bodleian Library de Oxford, y [B] a la edición de Adolfo Bonilla y San Martín, Libros de caballerías. Parte 2, Ciclo de los Palmerines Extravagantes Madrid, Bailly Baillière e hijos, 1908, pp. 377-401. Del siglo XVI, tiene una relación directa con la de Sevilla, pero desconocemos exactamente quién la editó y cuándo.

${ }^{12}$ David Hook, «The Legend of the Flavian Destruction of Jerusalem in Late Fiteenth-century Spain and Portugal», en Bulletin of Hispanic Studies, 65 (1988), pp. 113-128 (114).

${ }^{13} \mathrm{El}$ Gesamtkatalog der Wiegendrucke puede consultarse en línea, con la ventaja de estar actualizado. Enlace: <http://gesamtkatalogderwiegendrucke.de/> [Consulta: 13/03/2016], del mismo modo que el 
El incunable de 1499 , en $4^{\circ}$, debería tener 36 hojas, distribuidas de acuerdo con la colación $\mathrm{abc}^{8} \mathrm{de}^{6}$, si bien ya en el siglo XIX había perdidos dos folios, como se anota en el catálogo de Grenville: «It is apparently imperfect. Signature A has only six leaves, and no Title» ${ }^{14}$. Su información es similar a la que figura en la hoja de guarda del único ejemplar conocido, conservado en la British Library, posiblemente escrita por su propietario ${ }^{15}$, quien trataba de recalcar su rareza. Las pérdidas afectan a la primera, $\mathrm{a}^{1}, \mathrm{y}$ última hoja, $\mathrm{a}^{8}$, de su primer cuadernillo. Corresponde a uno de los 21 incunables españoles comprados por el bibliófilo inglés, no especialmente interesado por nuestra literatura, adquirido entre 1823 y1842 por $£ 616 \mathrm{~s}^{16}$.

Los epígrafes de sus 28 capítulos conservados, más la conclusión ${ }^{17}$, precedidos del correspondiente calderón y centrados, carecen de numeración ${ }^{18}$; se resaltan por emplear diferente tamaño de letra y separarse del segmento anterior y posterior a la rúbrica con sus respectivas líneas en blanco. En el inicio textual de cada uno se emplean mayúsculas de imprenta de cinco líneas, excepto en el antepenúltimo capítulo "Cómo el aguazil...», que por falta de espacio utiliza una capital de dos líneas.

Sus 15 xilografías han sido creadas ex profeso, siguiendo unos modelos perdidos, si bien no cumplen una función dispositiva como los epígrafes. Teniendo en cuenta que La Estoria del noble Vespasiano está segmentada en 30 capítulos más una conclusión, se deduce que se han ilustrado solo los episodios más significativos, a diferencia de la edición lisboeta. Se ha impreso un libro breve de relativo lujo, sin escatimar los sobrecostes que supone el

Incunabula Short Title Catalogue. [En línea]. Enlace: <http://www.bl.uk/catalogues/istc/ $>$ de la British Library [Consulta: 13/03/2016].

${ }^{14}$ John Thomas Payne y Henry Foss, Bibliotheca Grenvilliana, or Bibliographical Notices of Rare and Curious Books, Forming Part of the Library of the Right Hon. Thomas Grenville, London, William Nicol, 1842, vol. II, p. 764. Conrado Haebler, Bibliografia ibérica del siglo XV..., La Haya; Lepizig, Martinus Nijhoff; Karl W. Hiersemann, 1903, it. 674, propuso esta otra, ajustada a la realidad, pero no a su modelo originario: $\mathrm{a}^{6} \mathrm{bc}^{8} \mathrm{de}^{6}$.

${ }^{15}$ Este tipo de notas es característica de Grenville. Cfr. Barry Taylor «Thomas Grenville (1755-1846) y la bibliofilia hispánica», en Bibliofilia y nacionalismo: nueve ensayos sobre coleccionismo y artes contemporáneas del libro, dir. de M. Luisa López-Vidriero y ed. de Pablo Andrés Escapa, Salamanca, Seminario de Estudios Medievales y Renacentistas, Sociedad de Estudios Medievales y Renacentistas, 2011, pp. 304-319 (309).

${ }^{16}$ Ibídem, p. 312. Encuadernado en R[ed] M[arroco] se custodia con la signatura G.10211, con la sigla de haber pertenecido a la colección de Grenville.

${ }^{17} \mathrm{~A}$ ellos deberían sumarse otros dos del folio perdido, el $\mathrm{a}^{8}$ : «Como dixo el enperador que si Dios le dava salud que vengaría la muerte de aquel sancto profecta Christo» (212) y «De la oración que fazía la santa Veronica» (213).

${ }^{18} \mathrm{La}$ versión portuguesa numera sus 29 capítulos de forma correlativa, pero omite «Da grande alegria que foy na corte do emperador polla saude de seu senhor», por lo que su cifra total es también 30 más la conclusión. 
empleo de unos grabados de generoso tamaño, que acrecientan el precio del libro por las quince hojas añadidas, el 20,83\% del tamaño total de la obra, y los gastos del artesano entallador, que ha realizado un decoroso trabajo ${ }^{19}$. Solo en tres ocasiones, «De cómo llegó Gays en Jherusalén...», «De cómo desesperó el rey Archileus» y de «Cómo se bautizó el emperador ...», los impresores han incluido la xilografía inmediatamente después de la rúbrica, si bien la primera está descolocada.

La imagen, que ilustra un desplazamiento marítimo (grab. 1), se sitúa inmediatamente después del epígrafe, «De cómo llegó Gais en Jherusalén ...», pero el viaje mencionado en el capítulo es terrestre. Han partido desde Roma hasta Barlec, correspondiente al puerto de Barletta, en la Puglia imperial, lugar bien conocido en la tercera cruzada y en la Chanson d'Antioche ${ }^{20}$. Toman tierra en Acre y desde allí llegan al puerto de Jafa, que «es a tres jornadas de Jerusalem», hacia donde cabalgan Gais y los cinco caballeros que lo acompañan. Como reza el texto y refleja la xilografía portuguesa, el desplazamiento transcurre por tierra. Por el contrario, si el grabado se hubiera situado en el folio y capítulo anterior, se acomodaría a la orden del emperador, «Cómo el emperador envió buscar las reliquias de Jesuchristo por su senescal Gais», que implicaba un primer traslado por vía marítima, situación reflejada en la edición lisboeta ${ }^{21}$.

Si la primera estampa está mal colocada, en otros casos la ilustración está un poco alejada del texto del que depende, por lo que en una primera aproximación podríamos sugerir que las viñetas no tratan de transcodificar los signos verbales a otros gráficos de modo exacto, sino de reflejar situaciones significativas, memorables, como también lo atestiguan ciertos desajustes entre las palabras y sus grabados. A diferencia de la versión portuguesa, no se reitera ninguna xilografía, indicio de la condición específica de todas ellas, ligadas a unos textos concretos.

Martin Kruz las catalogó muy brevemente, s. v. Vengeance de Nôtre Seigneur ${ }^{22}$, descripciones que constituirán nuestro punto de partida con la indicación de sus dimensiones y de su localización en el impreso, si bien corregimos varios errores:

\footnotetext{
${ }^{19}$ José Luis Portillo Muñoz, La ilustración gráfica de los incunables sevillanos (1470-1500), Sevilla, Diputación Provincial de Sevilla, 1980, pp. 140-141, considera el libro como uno de los incunables sevillanos más interesantes desde el punto de vista ilustrativo.

${ }^{20}$ Véase Suzanne Thiolier-Méjean, La prise de Jérusalem par Vespasien. Une legende médiévale, Paris, L'Harmattan, 2012, pp. 42-44.

${ }^{21}$ La edición de Lyon, Jacques Arnollet, 1499, f. A ${ }^{3} \mathrm{v}$, ilustra el viaje con un barco, pero su capitulación y texto son diferentes a los de la tradición ibérica.

${ }^{22}$ Martin Kurz, Handbuch der iberischen Bilddrucke des XV. Jahrhunderts, Leipzig, Karl W. Hiersemann, 1931.
} 
Sevilla, 1. Viaje del senescal Gais (Caius) a Jerusalén para encontrar remedio a la enfermedad de Vespasiano y reclamar a Pilatos el tributo debido $\left(\mathrm{a}^{4} \mathrm{v}\right)$. $156 \times 95$.

Sevilla, 2. Curación de Vespasiano con el paño de la Verónica (b³r). 159 x 97. Sevilla, 3. Edificación de una nueva iglesia en Roma para custodiar la Santa Faz $\left(b^{4} v\right) .155 \times 98$.

Sevilla, 4. Destrucción del castillo de Jafa y solicitud de perdón de Jafel $\left(\mathrm{b}^{6} \mathrm{r}\right)$. $152 \times 98$.

Sevilla, 5. Negociaciones entre Vespasiano y Pilatos ( $\left.b^{7} v\right) .153 \times 102$.

Sevilla, 6. Suministro de agua a la hueste ( $\left.\mathrm{c}^{1} \mathrm{v}\right) .160 \times 102$.

Sevilla, 7 [12]. Liberación milagrosa de Jacob (c $\left.{ }^{3} r\right) .155$ x 100.

Sevilla, 8. Combate campal entre los ejércitos adversarios ( $\left.c^{5} r\right) .154$ x 101.

Sevilla, 9 [10]. La reina de África y Clarisa comen los cuerpos de sus hijos descuartizados $\left(\mathrm{c}^{8} \mathrm{v}\right) .152 \times 100$.

Sevilla, 10 [7]. Suicidio de Arquelao (d $\left.\mathrm{d}^{2} \mathrm{r}\right) .153$ x 100.

Sevilla, 11. Venta de 30 judíos por un dinero a un romano, y desentrañamiento de uno de ellos para obtener el oro y la plata comidos $\left(d^{3} \mathrm{v}\right) .154$ x 98.

Sevilla, 12. [9] Destrucción de Jerusalén ( $\left.\mathrm{d}^{5} \mathrm{v}\right) .153$ x 99.

Sevilla, 13. Salida en barco de los supervivientes judíos (e $\left.{ }^{1} \mathrm{r}\right) .153$ x 101.

Sevilla, 14. San Clemente bautiza a Vespasiano (e²v). 153 x 101.

Sevilla, 15. Castigo y muerte de Pilatos, en medio del río [Ródano], y arrastrado por tres diablos $\left(\mathrm{e}^{5} \mathrm{v}\right) .154 \times 93$.

De acuerdo con Dédier Méhu, una imagen adquiere su sentido a partir de tres diferentes tipos de relaciones establecidas a) entre sus propios componentes, b) en su conexión con otras imágenes y c) más allá del dominio visual ${ }^{23}$, que, a nuestro juicio, viene condicionado, entre otros factores, por el texto en el que se inscribe, por su lógica narrativa e ideológica y por el contexto sociocultural en el que se inserta, aspectos estos últimos a los que prestaremos mayor atención.

Los principales ejes argumentales de la Estoria del noble Vespasiano están reflejados desigualmente, pues la mayoría de los grabados, más del 60\%, ilustran la aniquilación de Jerusalén y el castigo de los judíos, con imágenes preferentemente de destrucción de edificios y personas, núms. 4, 9, 10, 11, 12 y 15 , y bélicos-caballerescas; estas no se limitan al enfrentamiento campal (8), ya que se visualiza el proceso de negociación (5), la preparación logística del asedio (6) y las consecuencias destructivas antes mencionadas. El castigo de Pilatos se representa solo en una estampa (15), significativa por la posición final que ocupa; en sentido opuesto, se dedica una imagen a la salvación

\footnotetext{
${ }^{23}$ Didier Méhu, «Les rapports dans l'image», en Les images dans l'Occident médiéval, ed. de Jérôme Baschet y Pierre-Olivier Dittmar, Turnhout, Brepols, 2015, pp. 275-290 (275).
} 
milagrosa de Jacob (7), que colaboró en la búsqueda de Verónica. Por otra parte, si Jerusalén es el centro espacial del relato, la llegada y salida de ese ámbito se simboliza mediante dos imágenes marítimas (1 y 13), relacionadas visualmente, pero contrastadas por su contenido; corresponden al final de Jerusalén (13) y al viaje de Gais para encontrar el remedio de Vespasiano (1). Este último apartado lo integran las imágenes núms. 1, 2, 3 y 14, desde la partida de Gais (1) hasta el bautismo del emperador (14), en las que nos detendremos más ampliamente; señalaremos las principales relaciones que establecen, pues sus paralelismos y contrastes seleccionan y potencian ciertas lecturas, aunque algunas ya estuvieran fijadas en el modelo iconográfico perdido.

\section{Los desplazamientos marítimos}

En el primer núcleo confluyen dos imágenes navales (grabados 1 y 2), relacionadas por la presencia de unos barcos de tres velas en los que se desplazan los personajes. En el primero, Gais parte de Roma hasta Acre, adonde marcha en busca de la reliquia milagrosa, con independencia de que la imagen esté descolocada. El contexto narrativo del segundo corresponde al regreso de Vespasiano. De forma paralela al inicio, permanece también tres días en Acre y sale desde Jafa, en un itinerario rememorativo, lógico e invertido respecto al emprendido por su senescal. Pese a estos paralelismos textuales, el grabado refleja los preparativos de tres naves en las que deben embarcar los únicos judíos supervivientes: «Fizo aparejar tres naves e en cada una destas tres naves fizo poner los judíos entre hombres e mugeres e criaturas» (249). El grabador ha dotado a los dos personajes más cercanos de narices prominentes, rasgos asociados a los judíos en la tradición. Son vigilados por soldados y, como prisioneros, están rodeados por una cuerda y marchan con sus manos atadas, del mismo modo que había sucedido tras la venta de treinta judíos por un 'dinero' $(11)^{24}$.

Si la primera embarcación se dirigía hacia Oriente, hacia la búsqueda de la salvación, podríamos esperar que los tres navíos finales reflejaran el éxito obtenido; de algún modo es así, pero, en un contraste visual calculado, el triunfo de Vespasiano representa el castigo de los judíos por la muerte de Cristo, cuya

\footnotetext{
${ }^{24}$ Refleja una iconografía bien conocida para representar a los prisioneros, asentada en manuscritos iluminados de los siglos XIII y XIV sobre la destrucción de Jerusalén. Véase Kathryn Smith, «The Destructtion of Jerusalem Miniatures in the Neville of Hornby Hours and their Visual, Literary and Devotional Contexts», en Journal of Jewish Art [The Real and Ideal Jerusalem in Jewish, Christian and Islamic Art. Studies in Honor of Bezalel Narkiss on the Ocassion of his Seventieth Birthday], 23/24 (1998), pp. 179202, figuras 2, 9, 14 y 15 .
} 


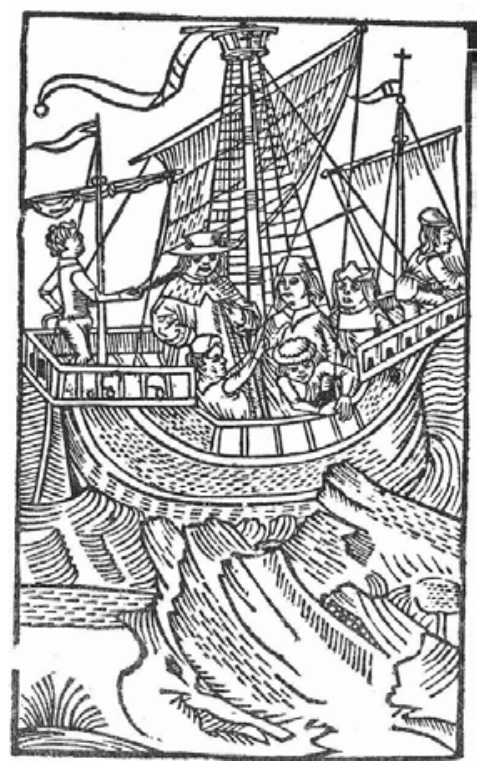

Grabado 1 (Sevilla, Pedro Brun, 1499, f. a ${ }^{4}$ v.) 156 x 95. Foulché-Delbosc, art. cit., p. 572.

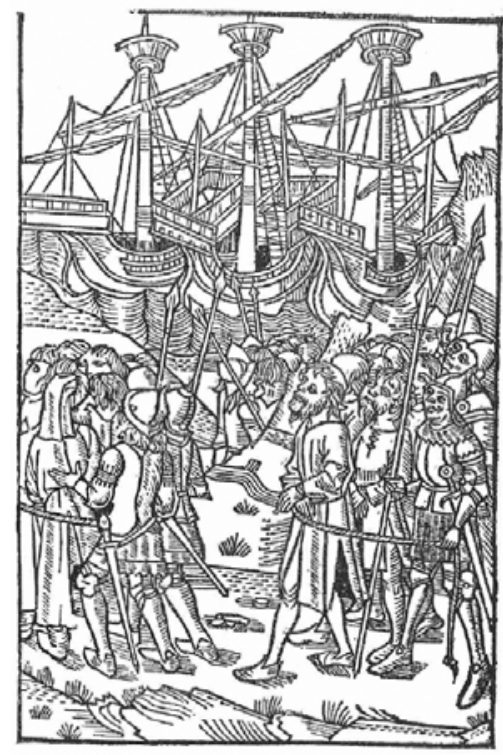

Grabado 2 (Sevilla, Pedro Brun, 1499, f. e ${ }^{1}$ r). 153 x 101. Foulché-Delbosc, art. cit., p. 623.

venganza había asumido el emperador. El episodio se ha relacionado con «une prière juive qui introduit le service du soir», que, además, se apoyaría en la realidad histórica, relacionada con el establecimiento «très précoce de foyers juifs dans les colonies romaines de Gaule $»^{25}$, pero también, como recuerdan los críticos, recrea una tradición folclórica y literaria bien conocida, la del barco sin timonel ni remos, que llega parodiada hasta el Quijote.

Para los hombres de la Edad Media el mar es fuente de continuos peligros, por lo que la ausencia de marineros y alimentos expone a los navegantes a una muerte casi segura; en estas circunstancias, en caso de éxito el viaje puede considerarse extraordinario, sea milagroso, maravilloso o mágico. Este desplazamiento puede identificarse con varios motivos folclóricos y literarios muy conocidos, pero en este caso los más específicos corresponden al Q466.0.1. Embarkation in rudderless boat as punishment de los índices de Thompson y al incorporado por Luna Mariscal, el V360.7 (L). God left some Jews alive to perpetuate the memory of their treachery ${ }^{26}$, subrayado por el texto:

${ }^{25}$ Suzanne Thioler-Méjean, ob. cit., pp. 21y 22, respectivamente.

${ }^{26}$ Véase David Hook, The Destruction of Jerusalem: Catalan and Castilian Texts, ob. cit., pp. 275276, y Karla Xiomara Luna Mariscal, Índice de motivos de las Historias caballerescas breves, Vigo, Editorial Academia del Hispanismo, 2013, p. 492. 
Nuestro Señor Jesucristo que quiso que la su muerte fuesse remembrada salvó todas las naves e cuan[t]os dentro eran, e vino arribar la una nave en Inglatierra e la otra en Burdeos e la otra en Narbona ${ }^{27}$. E todos salieron sanos e salvos, de la cual cosa ovieron grande gozo e placer, e cuidavan que Dios lo avía fecho por amor dellos, e fízolo porque todos tiempos fuesen vituperados e denostados e escarnescidos de todas las gentes por la su muerte; e fizo aý un grande milagro, que todos cuantos fueron a una nave todos avían de su tiempo bien assí como si mugeres fuesen (249).

La contigüidad narrativa de ambos sucesos sugiere una posible relación que va más allá de su proximidad textual. D. Hook sintetizó y explicó a la perfección el último, en un fragmento confuso en su transmisión: «all the Jews in one boat, males included, menstruate» [...] «Within the logic of the legend, it is, however, a gruesomely appropriate humiliation for the shedding of Christ's blood, possibly inspired by inversion of the miracle of the woman with the issue of blood ${ }^{28}$ ).

El acontecimiento muestra la capacidad divina para alterar el curso de la naturaleza - de ahí su condición milagrosa-, al tiempo que la venganza de Dios, al aplicar la ley del talión, en este caso de sangre por sangre. Recuerda la Pasión y la hemorroísa, con la que mantiene un paralelismo formal estrecho, pues se trata de una enferma (impura) por su flujo de sangre, curada tras tocar el manto de Cristo (Mt 9, 20-21; Mc 5, 25-33; Lc 8, 43-48). Habría logrado su recuperación gracias a su fe y a su contacto con Jesús, del mismo modo que sucederá con Verónica y con Vespasiano, como analizaremos más adelante. El contraste resulta ilustrativo: la cercanía espiritual y física acarrea la salvación y la curación; la animadversión y alejamiento, un castigo análogo a su culpa.

El segundo milagro implica la salvación de los navegantes gracias a la ayuda divina, un motivo que, a fines del siglo xv, fue utilizado en España como propaganda. Andrés Bernáldez estratégicamente contraponía dos comportamientos de Dios en la expulsión de los judíos de 1492. Según el autor, los rabíes habían prometido a quienes se fueran que, pese a las dificultades que pudieran encontrar en tierra, «entrando en la mar verían cómo Dios sería su guiador, como avía fecho con sus antepasados en Egipto» ${ }^{29}$. Sin embargo, según el interesado discurso posterior, sucedió lo contrario:

\footnotetext{
${ }^{27}$ Para Alvin E Ford, La Vengeance... The versión Japeht, ob. cit., p. 186, nota 1028, estas tres áreas no pertenecían entonces al reino de Francia, por lo que su selección podría considerarse un castigo político.

${ }^{28}$ David Hook, The Destruction of Jerusalem: Catalan and Castilian Texts, ob. cit., pp. 188-189, nota 62.

${ }^{29}$ Memorias del reinado de los Reyes Católicos que escribía el bachiller Andrés Bernáldez, ed. de 
Los que fueron a enbarcar por el puerto de Santa María e Cáliz, así como vieron la mar davan muy grandes bozes e gritos, onbres e mugeres, grandes e chicos, con sus oraciones demandando a Dios misericordia, e pensavan ver algunas maravillas de Dios e que se les avía de abrir camino por la mar ${ }^{30}$.

La contraposición pretendía desvelar la culpabilidad actual de los judíos, frente a su comportamiento anterior, pero en la Estoria del noble Vespasiano la venganza de Cristo es más sutil: se salva a los expulsados para recordar su maldad, lo que implica la continuidad del castigo en generaciones posteriores; la condena se actualiza de forma constante y puede ser esgrimida en la propaganda antisemita que justifica actitudes y decretos emanados desde el poder. Consistiría en una damnatio memoriae clásica en sentido invertido, recordando hechos considerados condenables para que no se olviden. Esta perspectiva duplica y legitima las represalias de Vespasiano, al actuar como el Dios cristiano; desde una óptica política, interviene como su representante en la tierra.

Literariamente estos barcos, «les nacelles pénales où l'on abandonne certains personnages, comme Caïphe, sont plus proches de l'hagiographie que celles que l'on trouve ordinairement dans les romans $\rangle^{31}$. De forma significativa, en el texto toledano y en el portugués los grupos parten del castillo de Caifás ${ }^{32}$, personaje cuya trayectoria literaria sigue un curso similar al de los judíos embarcados. Para no quemarlo ni ahorcarlo, como había prometido, Vespasiano lo pone en un batel según recoge el Libro de Josep de Arimatea: «E mandolo alongar por la mar e que fuese allá donde la ventura lo echase. Así vengó Vaspasiano a Jesucristo. E esto fue por mostrar enxiemplo a los judíos», motivo incluido en la Demanda del santa Grial, cap. $227^{33}$.

Manuel Gómez-Moreno y Juan de M. Carriazo, Madrid, Real Academia de la Historia, 1962, p. 254. Algunas tradiciones recogidas por Andrés Bernáldez podían proceder de la Estoria del noble Vespasiano. Véase David Hook, «Some Problems in Andres Bemaldez's Account Spanish Jews», en Michael: On the History of the Jews in the Diaspora, 11 (1989), pp. 231-255.

${ }^{30}$ Memorias del reinado..., ob. cit., p. 258.

${ }^{31}$ Jean-Olivier Signoret, Deo gubernante. Navigations miraculeuses et miracles marins au Moyen Age: l'union des cultures paiennes et chretiennes, Lille, Atelier National de Reproduction des Thèses, 2000, p. 423.

${ }^{32}$ Por el contrario, Sevilla lee Jafa, variante, a nuestro juicio, errónea. En la realidad existió este castillo, como indica Suzanne Thioler-Méjean, ob. cit., p. 302, nota 105.

${ }^{33}$ Tomo el texto de Bernard Darbord y César García de Lucas, quien hizo su tesis doctoral sobre el ms. artúrico, «Espacio, tiempo y movimiento en los textos artúricos del manuscrito 1877 de la Biblioteca Universitaria de Salamanca», en Cahiers d'études hispaniques médiévales, 30:1 (2007), pp. 197-213 (208); como señalan, cumpliendo con su promesa, Vespasiano no condena a Caifás a muerte, «a pesar de su responsabilidad en la muerte de Cristo y en la prisión de José de Arimatea. Lo condena a errar en un barco, sin rumbo fijo, en un continuo movimiento evocado por el itinerario errático del barco por la horizontalidad del mar», p. 207. Incluyen también la referencia del episodio de la Demanda, cap. 227. 
En la Estoria del noble Vespasiano ambos desplazamientos marítimos desbordan su aparente condición preliminar o epilogal, pues además de situar a la Ciudad Santa como centro del relato sintetizan también un desplazamiento político-religioso que conduce al nuevo centro, la Roma Imperial, por un lado, y la Roma cristiana, por otro, con el primer Papa. Finalmente, la cruz que guía el velero del inicio (1) se contrapone con la muerte de Pilatos, cuyo hundimiento en el abismo está representado por unos diablos (15).

\section{La curación de Vespasiano: Verónica y la Santa Faz}

El segundo núcleo, relacionado con el anterior, está representado por la actuación directa e indirecta de Verónica, correspondiente a las viñetas 2, curación de la lepra, 3, la construcción de la Iglesia y 14, el bautismo del emperador (curación del alma).

La leyenda del emperador gravemente enfermo y curado de forma milagrosa gracias al contacto con la efigie de Jesucristo se difundió durante la Edad Media, sobre todo, en dos relatos legendarios que llegaron a contaminarse: el del rey de Edesa, Abgar, quien, puesto en relación epistolar con Jesús, se curó por medio de su retrato, conocido como mandylion, al tiempo que obtuvo una carta que convertía a Edesa en inexpugnable ${ }^{34}$; la otra leyenda narra la curación de Tiberio gracias a la efigie (vera icona) trasladada por Verónica, según la tradición más difundida en el Occidente medieval. La modificación de Tiberio por Vespasiano se produce en sucesivas variaciones detalladas por A. Micha hasta llegar a la Vengeance de Nostre Seigneur y a la Estoire dou Grail de Robert de Boron ${ }^{35}$, que confluyen en la Estoria del noble Vespasiano.

En la obra se omite la causa de la enfermedad, pero puede deducirse de su descripción por cuanto adoraba a los ídolos, acumulaba grandes riquezas y se deleitaba en los vicios carnales (201). Como señaló Rosa, en un mundo en el que la dolencia y la muerte se consideraban resultado de los pecados del individuo, un personaje como Vespasiano «era emblematicamente impuro; por conseguinte merecedor de ser acometido por doença «forte \& fea", uma vez que incidia em dois dos três pecados mais graves segundo Tertuliano: a

${ }^{34}$ La tradición de la epístola la recoge de pasada la Primera crónica general de España que mandó componer Alfonso el Sabio y se continuaba bajo Sancho IV en 1289, ed. de Ramón Menéndez Pidal et alia, Madrid, Gredos, 1955, vol. I, p. 161. El tema tiene una bibliografía desbordante. Véase Gerhard Wolf, «"Or fu si fatta la sembianza vostra?". Sguardi alla "vera icona” e alle sue copie artistiche», en $I l$ volto di Cristo, ed. de Giovanni Morello y Gerhard Wolf, Milano, Electa, 2000, pp. 103-114 (114, nota 1).

${ }^{35}$ Alexandre Micha trazó las principales pautas de su difusión en Francia, art. cit. 
idolatria e a fornicação» ${ }^{36}$. Su curación se producirá después de su contacto físico con la imagen de la santa Faz de Cristo traída por Verónica, una de las representaciones más divulgadas en el arte medieval, en consonancia con el arraigo del personaje. "Les deux écrits apocryphes [Cura sanitatis Tiberii y Vindicta salvatoris], leurs versions en langues vulgaires et d'autres adaptations de leur matière assurèrent à la légende de Véronique une large diffusion en Occident $\gg{ }^{37}$. En tradiciones muy influyentes se identificaba con la hemorroísa como en el apócrifo Evangelio de Nicodemo (EN) y en la Vindicta Salvatoris (VS): «Y cierta mujer llamada Bernice (Verónica) empezó a gritar desde lejos, diciendo: "Encontrándome enferma con flujo de sangre, toqué la fimbria de su manto y cesó la hemorragia, que había tenido doce años consecutivos"» $(E N)$; «a Verónica, que venía padeciendo flujo de sangre durante doce años, le dio salud al tocar ella la orla de su vestido» $(V S)^{38}$. De forma similar, a fines del siglo xv lo subraya Martínez de Ampiés en una glosa al Viaje de la tierra santa:

Fue la Verónica una mujer santa de Jerusalem, discipla de Christo. Y es la misma de la qual haze mención el Evangelio de señor sant Lucas, a VIII capítulos: Que sanó del fluxo y mal de sangre tocando las faldas d'el redemptor Jesú; y después al tiempo de su passión muy dolorosa, viendo el amor de la mujer dicha, le demandó un paño blanco, donde, alimpiando el sudor de su vulto, dexó la ymagen de su faz preciosa, la qual guardó esta mujer santa como reliquia tan excellente de su Maestro. Después Tiberio, emperador de

\footnotetext{
${ }^{36}$ Maria Carlota Rosa, «A lepra numa obra medieval de ficção: A história do mui nobre Vespasiano imperador de Roma», en Cadernos Saúde Coletiva, 13:2 (2005), pp. 459-470 (465).

${ }^{37}$ Jean-Marie Sansterre, «Variations d'une légende et genèse d'un culte entre la Jérusalem des origines, Rome et l'Occident. Quelques jalons de l'histoire de Véronique et de la Veronica jusqu'à la fin du XIII ${ }^{\mathrm{e}}$ siècle», en Passages. Déplacements des hommes, circulation des textes et identités dans l'Occident médiéval: Actes du Colloque de Bordeaux (2 et 3 février 2007), ed. de Joëlle Ducos y Patrick Henriet, Toulouse, Université Toulouse II-Le Mirail, 2013, pp. 217-231 (224). Uno de los graves problemas para fijar bien sus orígenes y formación surge por la ausencia de una edición crítica de la Vindicta, como analiza Rémi Gounelle, «Les origines littéraires de la légende de Véronique et de la Sainte Face: la Cura sanitatis Tiberii et la Vindicta Saluatoris», en Sacre impronte e oggetti «non fatti da mano d'uomo» nelle religioni. Atti del Convegno Internationale - Torino, 18-20 maggio 2010, ed. de Adele Monaci Castagno, Torino, Edizioni dell'Orso, 2011, pp. 231-251. Para el mundo hispano, véase Etelvina Fernández González, «Del santo Mandilyon a la Verónica: sobre la vera icona de Cristo en la Edad Media», en Imágenes y promotores en el arte medieval. Miscelánea en homenaje a Joaquín Yarza Luaces, Bellaterra Universitat Autònoma de Barcelona, 2001, pp. 353-371, y Marta Crispí i Canton, «La Santa Faz de Cristo en la pintura gótica catalana. Iconografía y fuentes textuales», en Modelos, intercambios y recepción artística (De las rutas maritimas a la navegación en red), vol. II, Palma de Mallorca, Universitat de les Illes Balears, 2008, pp. 57-69. Para la literatura española, véase José Fradejas Lebrero, Los evangelios apócrifos en la literatura española, Madrid, Biblioteca de Autores Cristianos, 2005, pp. 327-374.

${ }^{38}$ Actas de Pilato o Evangelio de Nicodemo, VII, Venganza del Salvador, ed. de Aurelio de Santos Otero, Los evangelios apócrifos, $3^{\mathrm{a}}$ ed., Madrid, BAC, 1975, p. 418 y p. 528, respectivamente.
} 
los romanos, cayó en una dolencia muy grave. Y no fallando remedio alguno, fue la Verónica en Roma levada, sabida la grande reliquia suya; donde veniendo, luego que Tiberio tocó el vulto y faz preciosa, fue libre y sanó de sus dolores, a cuya causa, la santa matrona hovo gran favor. [...] Y duró fasta el tiempo del sancto padre Clemente, a quien dexó por testamento el santo vulto, que por nuestro tiempo guardan en Roma ${ }^{39}$.

Ahora bien, la Estoria del noble Vespasiano atribuye al personaje una enfermedad análoga a la padecida por el emperador, lo que potencia las analogías y hace más compacto su universo narrativo, al tiempo que se propician otras interpretaciones, de gran arraigo bíblico. El relato cuenta cómo una mujer llamada Verónica, cuya dolencia le hacía apartarse de otras gentes, se acercó al Calvario con profundo dolor al creer que la curaría Jesucristo, quien le dice al ponerse a su altura:

— «Muger, dame esse paño con que me alimpie la faz» ${ }^{40}$. E la sancta Verónica diógelo. E cuando el sancto profeta ovo alimpiado la su faz, tornógelo e díxole assí: «-Muger, alça esse paño, que con esse sanarás». E cuando la Verónica lo tovo assí, abrió el paño e vido en él la faz del sancto profeta, e luego fue sana e limpia de toda dolencia, bien assí como el día en que nasció por la buena crehencia que ella avía en el sancto profeta Jesucristo todopoderoso, que es e será por siempre (207).

No se especifica ahora esa gravísima enfermedad, pero no ofrece duda alguna: la versión catalana la denomina 'lebrosia' (153), y la edición toledana 'malata' (leprosa) (215), término que en la edición sevillana se convierte en 'enferma'. Esta impresión evita la voz 'maldita', pero una lectura atenta empareja su mal con el del emperador: «aquella muger que vos he aquí traído que estava bien así como vos» (211).

El nombre de Verónica, procedente del griego Berenice, se interpreta como contracción de vera icona, imagen verdadera, índice «della dialettica immanente in tutta la storia dell'inmagine di Cristo ${ }^{41}$. Se trata de una efigie milagrosa, de las denominadas aquiripoyetas (no hechas por manos de hombre), y más en concreto brandea («reliquias por contacto»), resultado «de una

\footnotetext{
${ }^{39}$ Bernardo de Breidenbach, Viaje de la Tierra Santa, ed. de Pedro Tena Tena, Zaragoza, Institución «Fernando el Católico», 2003, p. 192.

${ }^{40}$ Las ediciones incunables francesas de la Destruction de Jérusalem que tengo a mano recogen otra tradición. La Faz quedó impregnada en la toalla que llevaba Verónica y que le entregó al pie de la Cruz a la virgen María: «Je y fus et nostre dame saincte Marie sa chiere rnere prist vne touaille que iauoye en ma teste et la mist deuant la fa//ce de Jhesucrist et puis elle la me bailla et tãtost ie fus saine et guerie», ed. de Barbosa, pp. 28-29.

${ }^{41}$ Gerhard Wolf, art. cit., p. 103.
} 
impresión mecánica acontecida durante la vida de su modelo» ${ }^{42}$. La tradición ofrecía dos principales posibilidades de representar a Cristo, imagen ideal e imagen sufriente, si bien el entallador sevillano eligió una intermedia, de mirada frontal, sin corona de espinas pero con huellas de los castigos recibidos.

Desde una perspectiva cristiana, a diferencia de las imágenes de las divinidades paganas a las que adora Vespasiano, su veracidad estaba autentificada en cuanto que la había obtenido la interesada, sobre quien había actuado de forma milagrosa. Se trataba «del retrato auténtico de una persona real y, por ello, podía dar testimonio de la naturaleza humana de Cristo contra las dudas de otras confesiones cristianas» ${ }^{43}$, y no cristianas, añadimos por nuestra parte. A su vez, el lector tiene el privilegio de poder ver una figura que supondría «un adelanto de la visión divina, pues en ella residía la esencia de la vida en el Cielo. En la "imagen auténtica", con la realidad invisible de Dios se hallaban unidos indisociablemente los rasgos terrenales de Jesús, visibles para el ojo humano, es decir, accidentes de una presencia perceptible con la mirada $\rangle^{44}$. La imagen podría considerarse una "consolazione visiva per l'assenza di Cristo dopo l'Ascensione, che diviene anche portatrice di grazia attraverso l'indulgenza» ${ }^{45}$. Además, el receptor de la Estoria del noble Vespasiano podría recordar -revivir-, el Via Crucis, la Pasión sobre la que se proyectaba una obra temporalmente sucedida tiempo después.

En la España de finales del siglo xv se multiplicaba la presencia de la Verónica tanto en las letras hispanas, como en las imágenes. Limitándome a Toledo y Sevilla, sabemos que en la primera se representaba una obra titulada $\mathrm{La} \mathrm{Ve}$ rónica 1493, en la que aparecían María, la Magdalena y las otras dos Marías. San Juan llevaba su habitual melena, mientras que Verónica «tenía un paño de Bretaña con el rostro de Cristo pintado al óleo» ${ }^{46}$; en la catedral se conserva una talla de madera de la «santa», que muestra el retrato de Cristo. "Concebida la escultura para estar adosada, debió de formar parte de un conjunto teatral de Misterios de la Pasión ${ }^{47}$. A su vez, el 10 de octubre de 1493 ante un escribano sevillano, Estanislao Polono testificaba haber impreso «cincuenta mil verónicas en pergamino por encargo del obispo de Jaén Luis Osorio (1483-1496)»,

${ }^{42}$ Hans Belting, Imagen y culto. Una historia de la imagen anterior a la edad del arte [1990], trad. Cristina Díez Pampliega y Jesús Espino Nuño, Tres Cantos, Akal, 2009, p. 74.

${ }^{43}$ Ibídem, p. 298.

${ }^{44}$ Ibidem, p. 279.

${ }^{45}$ Gerhard Wolf, art. cit, p. 110.

${ }^{46}$ Carmen Torroja Menéndez y María Rivas Palá, Teatro en Toledo en el siglo XV. «Auto de la Pasión» de Alonso del Campo, Madrid, Real Academia Española, 1977, p. 66. Por el esquema de personajes podría haber obtenido la Santa Faz al pie de la Cruz, de acuerdo con otras tradiciones.

${ }^{47}$ Etelvina Fernández González, art. cit., p. 362. 
identificables con el Santo Rostro de Jaén, la versión española del Mandylion, si bien desconocemos ejemplares de esta impresión ${ }^{48}$.

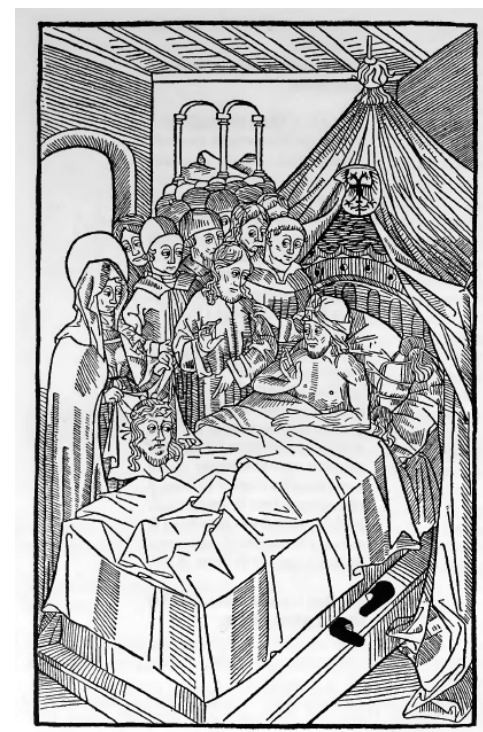

Grabado 3 (Lyon, Pierre Boutellier, h. 1488)

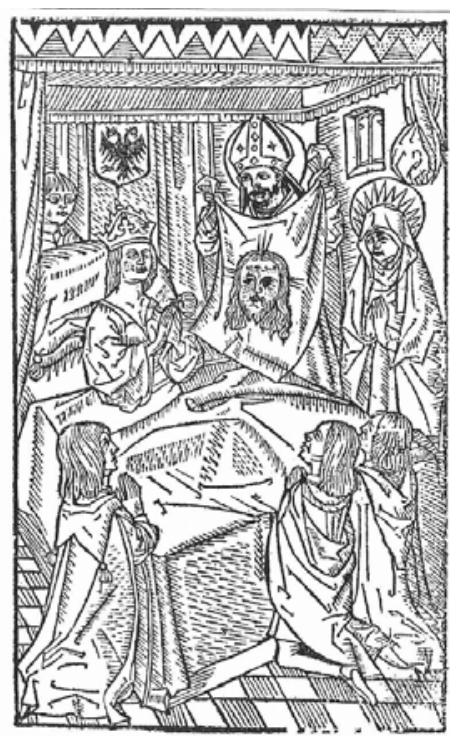

Grabado 4 (Sevilla, Pedro Brun, 1499, f. b ${ }^{3}$ r). 155 x 98 . Foulché-Delbosc, art. cit., p. 584.

La xilografía de la curación de Vespasiano figura en varias ediciones francesas de la Destruction de Jerusalem como contraportada, prueba de su importancia. Al remontarse al mismo episodio, las imágenes coinciden en sus grandes rasgos, sin que las similitudes puedan atribuirse a la casualidad, al tiempo que difieren en múltiples detalles. En la francesa el rostro del emperador no se representa deteriorado (grabado 3), mientras que en la española se perciben ciertas huellas de su enfermedad en la mejilla derecha, sin que por ello pierda su decoro (grabado 4).

Para nuestro interés, destacaremos que el grabado francés (grabado 3$)^{49}$, de una ejecución más refinada, sitúa al enfermo, incorporado en la cama, bajo un dosel cónico, con el pecho descubierto y su mano derecha abierta, señal de disponibilidad, aceptación, adhesión ${ }^{50}$. Por el contrario, en la xilografía

${ }^{48}$ Felipe Pereda, Las imágenes de la discordia. Política y poética de la imagen sagrada en la España del cuatrocientos, Madrid, Marcial Pons, 2007, p. 273.

${ }^{49}$ Lo retomamos de Anatole Claudin, Histoire de l'imprimerie en France au XV et au XVI ${ }^{e}$ siècle, vol. III, Paris, Imprimerie Nationale, 1904, p. 436. El grabado también lo empleó, entre otros, Jacques Maillet, Lyon, 1494, y fue modelo del reproducido en el vol. IV de Anatole Claudin, publié sous la direction de Léopold Delisle par Paul Lacombe, Paris, Imprimerie Nationale, 1914, p. 505, y del empleado por Jacques Arnollet, Lyon, 1499, bastante más tosco.

${ }^{50}$ François Garnier, Le langage de l'image au Moyen Âge. Signification et symbolique, Paris, Le 
sevillana, (grabado 4), que imita el mismo arquetipo que la portuguesa, el emperador, también incorporado en su cama, debajo de un dosel cuadrado, lleva el torso cubierto, tiene las manos unidas en actitud de rezo y se presenta con corona, en un claro ejemplo, por un lado, de dignificación del poder y, por otro, de sumisión a la imagen divina, aspectos más acusados en la xilografía sevillana que en la francesa. Los testigos situados alrededor de la cama, como si fueran orantes en actitud de rezo, y como Verónica, se representan con idéntica gestualidad. El nimbo de la mujer del grabado sevillano es de carácter estrellado, a diferencia del francés, que carece de ornamentos.

La mayor diferencia radica en que en la xilografía francesa su poseedora despliega la Santa Faz, que tiene marcada la corona de espinas, mientras que la imagen hispalense carece de ella ${ }^{51}, y$, de acuerdo con el texto español, la sostiene san Clemente, identificado por su mitra. Los textos franceses que he podido consultar hablan en plural refiriéndose a san Clemente y la Verónica, a veces con unos pronombres confusos - «ils desploierent la touaille [...] et la desploierent deuant lempereur $\rangle^{52}$ - por lo que tampoco resulta extraño que la «toalla» la sostenga Verónica, asumiendo el prototipo más extendido en la geografía europea, presente también en la Misa de san Gregorio, en el «Varón de Dolores» o en las Arma Christi ${ }^{53}$.

La Santa Faz funciona como reliquia curativa que sirve para limpiar de impurezas tanto corporales como espirituales, de modo que el cuerpo abyecto se convierte en significante como expresión del pecado y de la gracia ${ }^{54}$. En la tradición imperial antigua existe una estrecha relación entre el cuerpo del princeps y la res publica, «tra l'incolumità dell'imperatore e la salus populi.

Léopard d'Or, 1982, p. 174 y ss.

${ }^{51}$ Según John Oliver Hand, «Salve sancta facies: Some Thoughts on the Iconography of the Head of Christ' by Petrus Christus», en Metropolitan Museum Journal, 27 (1992), pp. 7-18, «The Crown of thorns becomes something of an independent variable, not necessarily connected with the devotional or narrative functions of the image», p. 16. A su vez, las huellas del sufrimiento de Cristo y Vespasiano responden a su condición redentora y pecaminosa respectivamente. Según Cristina González, «Horror and Ambiguity in La Historia del Noble Vespasiano», Cincinnati Romance Review, 36 (2013), pp. 85-95, el emperador está representado con un «visible hole in his right cheek», p. 91.

${ }^{52}$ La Vengeance...The versión Japeht, ob. cit., p. 80, «il deploierent veant tous la touaille». El sintagma en plural figura desde la princeps, Genève, Adam Steinschaber, 1479, s. f., hasta la de Lyon, Jacques Arnollet, 1499, f. B ${ }^{1} \mathrm{v}$. En versión catalana «sent Clement desplega la tovallola» (161).

${ }^{53}$ Etelvina Fernández González, art. cit., p. 361. El lector interesado puede encontrar una extraordinaria colección de Verónicas de todas las épocas. [En línea]. Enlace: $<$ https://veronicaroute.com/ $>$ [Consulta: 12/03/2016].

${ }^{54}$ Véase Louise M. Haywood, «El cuerpo como significante en el exemplum 44 del Conde Lucanor de don Juan Manuel», en Textos medievales: recursos, pensamiento e influencia. Trabajos de las IX Jornadas Medievales, ed. de Concepción Company; Aurelio González; Lillian von der Walde, México, D. F., El Colegio de México; Universidad Autónoma Metropolitana; Universidad Nacional Autónoma de México, 2005, pp. 205-214 (214). 
Nel corso della cristianizzazione, il motivo della lebbra si arricchisce di altri significati, rimandando al peccato ${ }^{55}$, hasta llegar a ser la metáfora absoluta suya, expresando, simultáneamente, la falta y la sanción ${ }^{56}$. Las ideas medievales sobre la enfermedad y sus enfermos, tanto como la de los textos médicos, proceden sobre todo de la Escritura y de la tradición, fijada especialmente en comentarios de los Santos Padres, Jerónimo, Ambrosio, Agustín, Isidoro de Sevilla, etc. Los pasajes del Antiguo y Nuevo Testamento en los que aparecen la lepra y los leprosos fueron objeto de múltiples comentarios ${ }^{57}$. Así, para san Ambrosio correspondía a la alegoría del pecado original ${ }^{58}$, conexión bien establecida y difundida en fechas cercanas a la publicación de la Estoria del noble Vespasiano.

La Vita Christi de Ludolfo de Sajonia $(\dagger 1378)$ alcanzó gran éxito a fines del siglo XV como dan cuenta los 33 incunables catalogados, la mayoría en latín comenzando por la edición de Colonia, Arnold Ther Hoernen, h. 1472, pero también en holandés (1487), francés (1487), portugués (1495) y catalán (1495), por limitarme a las primeras versiones incunables. En la traducción castellana de Ambrosio de Montesino, Alcalá, Polono, 1502-1503, al hablar de la curación del leproso por Jesucristo, de acuerdo con Mt 8, 1-4 (Mc 1, 40-45, Lc 5, 12-14), que "cántase en la segunda doménica después de la epiphanía», señala lo siguiente:

Pues hablando agora según seso espiritual, el leproso significa el linaje humano contaminado de la lepra del pecado original, y por este pecado tiene ya inclinación y apareja (sic) para caer en diversos pecados. E por la lepra, que es una enfermedad torpe, asquerosa y que se pega, es significada la culpa de Adam, que fue heredada y contraída en todos sus descendientes por generación carnal, la cual, tocada de la mano de Jesucristo, luego sana, porque por la virtud suya es alimpiada por la satisfación del baptismo la culpa figurada en ella. Por el ofrecimiento del don y por la publicación de la obra es figurado que el baptizado es obligado a servir fielmente a Dios y a lo alabar cada día. Por lo cual dize Beda: «este leproso es figura del linaje humano, todo flaco e doliente e contaminado de pecados y lleno de lepra porque todos pecaron e han menester la gracia de Dios, según el Apóstol dize» ${ }^{59}$.

\footnotetext{
${ }^{55}$ Gerhard Wolf, art. cit., p. 105.

${ }^{56}$ Marta Madero, Manos violentas, palabras vedadas. La injuria en Castilla y León (siglos XIII-XV), Madrid, Taurus, 1992, p. 65.

${ }^{57}$ Françoise Bériac, Histoire des lépreux au Moyen Âge, une societé d'exclus, Paris, Imago, 1988, p. 87.

${ }^{58} \mathrm{Ibídem}$, p. 95 y ss.

${ }^{59}$ Utilizamos la edición de La segunda parte del Vita Chirti cartuxano, Sevilla Juan Cromberger, 1543, f. Vr. Para la versión de Montesino, véase Carlos Moreno Hernández, «Traducción y paráfrasis en Fray Ambrosio Montesino», Los franciscanos y el contacto de lenguas y culturas, ed. de Antonio Bueno García, Praga, Universidad Carolina de Praga; Karolinum, 2013, pp. 127-144. Los Evangelios e epistolas
} 
Siguiendo la tradición, podríamos hablar de dos lepras imbricadas, la del cuerpo y la del alma, para cuya curación se requieren dos procedimientos complementarios. La primera tras la muerte de Jesús no puede eliminarse mediante la relación directa con él, como le sucedió a Verónica, pero sí a través de la reliquia de su figura:

Sant Clemiente desenbolvió el sancto paño a vista de todos, e llegáronse al emperador e fízole adorar la figura de la faz de Jesucristo. E como el emperador ovo adorado el sancto paño en virtud del sancto profeta, sant Clemiente lo puso en la cara del emperador. E luego en essa hora fue sano e limpio de la su dolencia bien ansí como si en algund tiempo no oviesse avido dolencia alguna (217).

Si uno de los remedios para la curación de la lepra era el baño de sangre, como ejemplificaban los relatos de figuras históricas (Constantino) o novelescas (Siete sabios de Roma, Oliveros de Castilla), el contacto con un paño con la figura de Cristo camino de la Cruz no hacía más que reflejar translaticiamente idéntico motivo ${ }^{60}$. Al fin y al cabo, el problema de la lepra afectaba, en creencia de larga duración, a la sangre, que debía ser purificada, si bien la mejor limpieza procedía del contacto con Cristo o con el cristianismo.

La otra curación de Vespasiano corresponde a la del alma, para lo cual necesariamente se requería la fe y el bautismo. Significativamente, este episodio se desplaza al final, por lo que todo el relato de la destrucción de Jerusalén, centro de la obra, constituye el «contradon» ofrecido por Vespasiano como agradecimiento por la desaparición de la lepra y la señal de su nueva fe, en una simplificación narrativa e ideológica. La imagen se centra en el primer bautismo de los celebrados, el del Vespasiano, pues después lo recibirán Tito, Jacob, Jafel, etc. Todos ellos han ayudado previamente al emperador, de modo que con diferentes modulaciones siguen el arquetipo del no cristiano

con sus exposiciones en romance según la versión castellana del siglo xv hecha por Gonçalo García de Santa Maria del texto de Guillermus Parisiensis: Postilla super epistolas et evangelia, ed. de Isak Collijn y Erik Staaf, Uppsala; Leipzig, Akademiska Bokhandeln; Otto Harrassowitz, 1908, p. 53, esgrimían un concepto similar: «Dize Hugo del Prado que enla scriptura fallamos la leprosia auer sido alimpiada en tres maneras que significan .iij. maneras de perdonar los peccados. La primera fue enel lauar del agua, como la lepra de Naaman. Según se muestra enel quarto delos Reyes .v. capitolos. E significa el baptismo enel qual todos los peccados son alimpiados: assi fue alimpiado Constantino corporal e spiritualmente conuiene a saber enel cuerpo e enel alma».

${ }^{60}$ No obstante, en otros relatos de la Vengeance de Notre Seigneur para la recuperación bastaba la mirada, como en la versión prosificada manuscrita de Japheth. Vespasiano se cura «la mirant [la touaille] devant l'empereur et la lui firent adorer», ed. de Albin Ford citada, p. 80. De igual modo sucede en la edición de Genève, en la de París, y en la de Lyon, 1499: «Et tantost qu'il eut adoree il fut aussi sain que se iamais il neust este malade» (f. $\left.\mathrm{B}^{1} \mathrm{v}\right)$. mientras que sí figura en la tradición catalana de la que dependen los otros textos ibéricos: «E como hac adorat e la hac tocado, ell fon de mantinent guarit e mundat de tota sa lebrosia...», David Hook, The Destruction of Jerusalem: Catalan and Castilian Texts, ob. cit., p. 161. 
convertido, tras un proceso en el que han demostrado su colaboración en la venganza emprendida por Vespasiano, que, en definitiva, no deja de ser un aspecto de la «venganza del Señor». El texto subraya que excepcionalmente ni a Vespasiano ni a Tito le modificaron su nombre, como a Verónica, en un intento de acomodar ficción narrativa y trasfondo pretendidamente histórico.

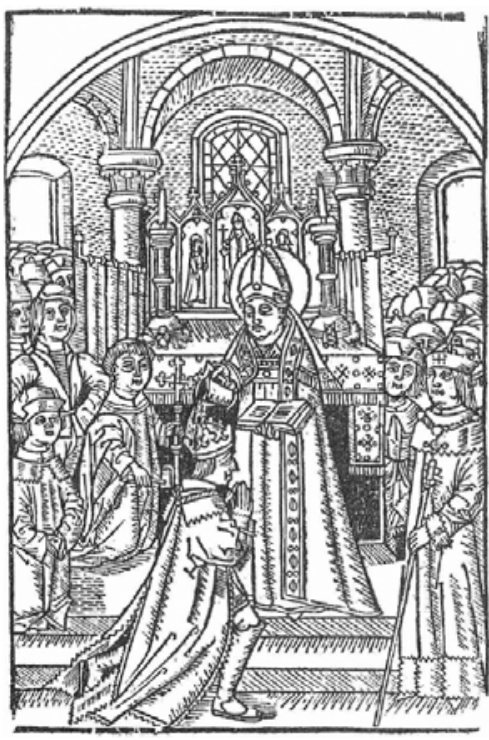

Grabado 5 (Sevilla, Pedro Brun, 1499, f. e ${ }^{2} v$ ). 153 x 101. Foulché-Delbosc, art. cit., p. 625.

La correlación entre las imágenes de la curación y el bautismo ejemplifican los dos aspectos del discurso religioso que además quedan plasmadas visualmente y a posteriori permiten hipotéticamente explicar por qué en la tradición del texto español san Clemente despliega la Faz de Cristo. Es también el encargado del bautismo de Vespasiano, $\mathrm{y}$ en la imagen lleva la misma mitra y aureola identificativas (grabado 5), del mismo modo que el emperador, con corona, une sus manos en señal de rezo, como las juntaba en su curación física. La celebración se realiza mediante el derramamiento de agua en su cabeza coronada, ante un altar mayor, en el que se divisa un políptico en cuyo centro se atisba la figura de un obispo con la cruz en la mano (la imagen dentro de la imagen). La equiparación entre la Santa Faz (es decir, la representación de Cristo) y el bautismo queda recalcada en el texto también por sus efectos, capaz de borrar las impurezas corporales:

E Nuestro Señor fizo aquí un grande milagro en esa ora, que todos cuantos aý eran que se fizieron cristianos fueron todos maravillados, que de cualquier enfermedad o dolencia que oviesen antes del bautismo luego que fueron bautizados se fallaron sanos e linpios de la dolencia bien assí como si todos tiempos oviesen estados sanos (253).

Las imágenes y los textos enlazan ambos acontecimientos, que además tienen en la España de finales del siglo Xv otro alcance. Ludolfo de Sajonia identificaba al pecador con el leproso a partir de una serie de analogías que en la época podían leerse con claves adicionales: según «moralidad», el leproso equivale al pecador por varias razones: el mal puede extenderse, corrompe los cuerpos y las almas, es de mal olor, como los pecados, los leprosos viven apartados, como los 
pecadores de la gracia de Dios, y porque así como la lepra tiene distintos colores, del mismo modo el alma leprosa está contaminada de todos los pecados ${ }^{61}$.

La equiparación entre pecador y leproso justificaba la necesidad de evitar la contaminación de la falta espiritual entre la comunidad, por lo que era necesario mantener al pecador apartado. Desde estas mismas bases metafóricas, el leproso se asociaba al traidor, como sucede en las Partidas, VII, II, 1, al excomulgado o al hereje ${ }^{62}$, es decir a todo al que se pretendía situar en los márgenes. Dadas estas características, no resulta extraño que entre ellos se incluyera a los judíos: «une habitude s'invétère rapidement de voir dans les lépreux châtiés de l'Écriture la figure des juifs ou des hérétiques, ceux qui ne sont pas entrés dans l'assemblée des baptisés, ou s'en son retranchés. Il s'agit bien là d'un lieu commun dès baptisés, ou s'en sont retranchés $\rangle^{63}$.

Los lugares comunes, incluso por su misma esencia, resultan difíciles de desterrar y persisten a lo largo del tiempo, y más en casos como el que nos ocupa que parten de unas mismas bases metafóricas, reflejo de una ideología y de un sistema social en el que adquieren plenitud de sentido. De acuerdo con Gutwirth, la mayoría de las reacciones europeas ante la expulsión de los judíos de 1492 «han sido denominadas con escasa exactitud como «antisemíticas». Abundan las imágenes de enfermedad. Los judíos fueron comparados a una lepra de la que España se había curado o a un tumor que había sido extirpado mediante cirujía ${ }^{64}$. Idéntica metáfora era utilizada en España hacia 1495-96, por Rodríguez de Montalvo al hablar de la expulsión: «E no contentos con esto, limpiaron de aquella suzia lepra, de aquella malvada heregía, que en sus reinos sembrada por muchos estava, assí de los visibles como de los invisibles» ${ }^{65}$. Desde la óptica interesada de la Estoria del noble Vespasiano, la lepra (física y espiritual) se curaba mediante la fe en Cristo a través del bautismo; así, se redimen personajes como Verónica, Jafel, Vespasiano, etc., y del mismo modo querrían las autoridades que reaccionaran los hebreos hispanos o, en caso contrario, serían expulsados ${ }^{66}$.

\footnotetext{
${ }^{61}$ Ambrosio de Montesino, ed. cit., f. Vr y v.

${ }^{62}$ Véase Emilio Mitre, «Muerte, veneno y enfermedad, metáforas medievales de la herejia», en Heresis, 25 (1995), pp. 63-84 (74-78).

${ }^{63}$ Françoise Bériac, ob. cit., p. 99.

${ }^{64}$ Eleazar Gutwirth, «Hacia la expulsión: 1391-1492», en Los judios de España: la diáspora sefardí desde 1492, ed. de Elie Kedourie, Barcelona, Crítica, 1992, pp. 47-71 (70-71).

${ }^{65}$ Garci Rodríguez De Montalvo, Sergas de Esplandián, ed. de Carlos Sainz de la Maza, Madrid, Castalia, 2003, cap. CII, pp. 566-67.

${ }^{66}$ Véase David Hook, «The Legend of the Flavian Destruction of Jerusalem in Late Fiteenth-century Spain and Portugal», art. cit., y Javier Castaño, «Profetismo político pseudo-Isidoriano en autores judíos de Castilla y Fez en torno a 1492», en Judios en tierras del Islam. Entre el Islam y Occidente. Los judios magrebies en la Edad Moderna, coord. por Mercedes García-Arenal, Madrid, Casa de Velázquez, 2003, pp. 1-25 (13-16).
} 


\section{La construcción de la Iglesia: la custodia de la Santa Faz}

La Santa Faz curativa, reliquia excepcional, será preservada en una iglesia creada ex profeso de acuerdo con la Estoria del noble Vespasiano, a la que el entallador le dedica una expresiva xilografía, bastante diferente de la portuguesa, en función del texto que ilustra:

Después qu'el emperador ovo elegido apostólico e cabeça de la cristiandad, fízole edificar una iglesia a honra e servicio de Dios e aquí fizo poner el santo paño do estava figurada la faz de Jesuchristo porque las gentes oviessen mayor devoción, e después establesció las fuentes en las cuales fue bautizada Verónica primeramente (219).

La autoridad imperial selecciona al Papa en un acto inaugural, instaurado con una reliquia que preside la nueva iglesia de san Simón el Justo, como se dirá después, en la que destacan sus «fuentes», recordando, de paso, que allí se había bautizado Verónica. En los textos castellanos y en el portugués, el nombre está ausente en el capítulo de la construcción de la iglesia, a diferencia de la versión catalana, pero aparecerá después al referirse al bautismo de Vespasiano. Los críticos la han identificado con san Pedro de Roma por una serie de confusiones, en donde se exhibía la reliquia ${ }^{67}$.

Como en otros casos, el grabado carece de sentido histórico tanto por el hecho en sí, su protagonista (Vespasiano) y el tipo de arquitectura; el entallador ha diseñado una iglesia gótica de tres naves con arcos conopiales, característicos a partir de la segunda mitad del siglo XV aunque en contradicción con el arco de medio punto de la espadaña; ahora bien, la xilografía no pretende reflejar un modelo concreto al tiempo que los textos medievales también adquieren un sentido desde el tiempo de su escritura, reedición o reelaboración. Durante la Edad Media es bien conocida la importancia de las reliquias en la construcción de las iglesias, como ejemplifican la Sainte-Chapelle (París), la catedral de Colonia o Santiago de Compostela por limitarnos a tres ejemplos emblemáticos. Así, la Santa Faz requería imaginariamente un espacio sagrado específico que la cobijara, que significativamente iba acompañada de sus fuentes (bautismales), aunque no se destacan en la imagen. Sin detallar todos los datos, en la realidad histórica (1197) Celestino III mando construir un ciborio que acogiera la Santa Faz, que bajo su antecesor destacaba a la luz de

\footnotetext{
${ }^{67}$ Según Alvin E. Ford, La Vengeance... The versión Japeht, ob. cit., p. 85, «probably St. Peter (known as Simon Peter and designated as "Simeon" in Acts 15:14) is intended and this would be acceptable in terms of the dates». Para Suzanne Thioler-Méjean, ob. cit., nota 22, p. 365, «"Simon le Juste" est un sens possible, mais peu probable dans un contexte chrétien», por lo que se inclina por una confusión entre Simón y Judas.
} 
diez lámparas. «Cette attention croissante pour la Veronica en tant qu'objet de culte s'inscrit dans le contexte de la rivalité entre les basiliques du Latran et du Vatican pour la primauté parmi les églises de la chrétienté» ${ }^{68}$.

La imagen fue ganando mayor relevancia, por sus orígenes y su condición "sagrada», convertida en objeto de culto por Inocencio III, exhibida en procesión a partir de 1208; un milagro sucedido en 1216 propició nuevas indulgencias a quienes rezaran una oración ante la efigie, lo que acrecentó el número de peregrinos que acudían a verla. De su popularidad da buena cuenta la acuñación de monedas y las sencillas reproducciones que podían obtener los peregrinos de los pintores de verónicas apostados en lugares cercanos al centro de peregrinaje ${ }^{69}$.

En la extensión de su culto fue decisiva la concesión de indulgencias, creciente con el paso del tiempo. "Innocent IV granted an indulgence of forty days for reciting the prayer Ave facies praeclara, and the later Salve sancta

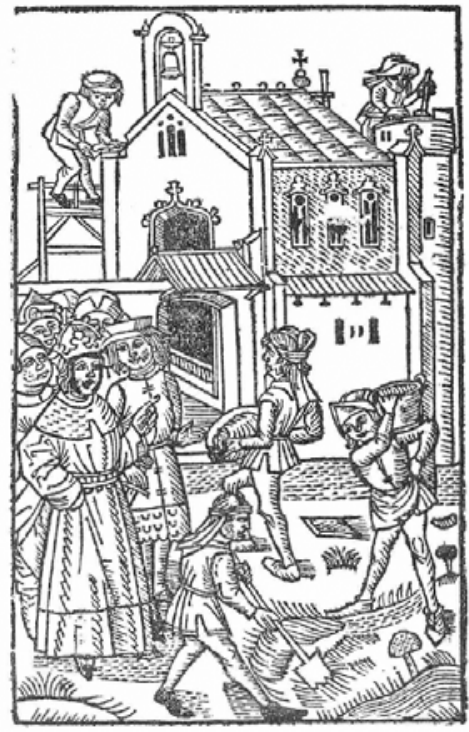

Grabado 6 (Sevilla, Pedro Brun, 1499, f. b ${ }^{4} v$ ).

155 x 98. Foulché-Delbosc, art. cit., p. 586.

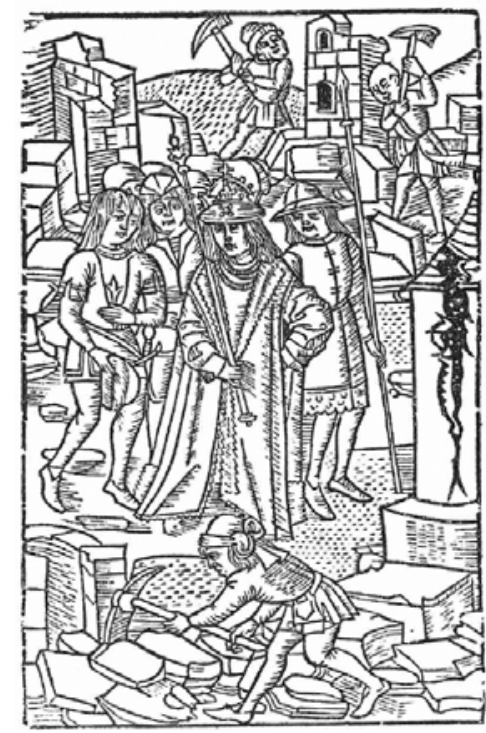

Grabado 7 (Sevilla, Pedro Brun, 1499, f. d $\mathrm{d}^{5} \mathrm{v}$ ). 153 x 99. Foulché-Delbosc, art. cit., p. 620.

facies gained one of at least ten thousand days. The value of the indulgence increased exponentially over time, and the indulgenced prayer was crucial for the dissemination of the Veronica cult ${ }^{70}$. Incluso no se requería ir a Roma para

\footnotetext{
${ }^{68}$ Jean-Marie Sansterre, art. cit., p. 222.

${ }^{69}$ Véase Gerhard Wolf, art. cit., Etelvina Fernández González, art. cit., pp. 359-360, y Marta Crispí i Canton, art. cit., p. 59.

${ }^{70}$ John Oliver Hand, art. cit., p. 14.
} 
conseguir tales concesiones, pues bastaba rezar la oración atribuida a Inocencio, «di norma davanti a una "copia" dell'immagine romana, quali se ne trovavano in numero crescenti in ambienti no solo monastici, ma anche laici» $\rangle^{71}$.

El lugar tan privilegiado que custodiaba su efigie no podía faltar entre los Mirabilia urbs Romae, y, en consecuencia, ser citado a fines del siglo xv por Martínez Ampiés en su Tratado de Roma, incluido en su traducción del Viaje de la Tierra Santa, obra en la que Bernardo de Breidenbach indicaba la localización de la casa de Verónica en Jerusalén:

En esta misma yglesia [el Vaticano] tienen la verónica siquiere vulto de la preciosa faz de Jesuchristo, redemtor nuestro, que se demuestra por muchas vezes la Semana Sancta, en el día de la Ascensión y el domingo luego después de sant Anthón, abad.

Primero llegamos a casa de la sancta Verónica, que se aparta de la de Pilato fasta $\mathrm{V}$ cientos y $\mathrm{L}$ passos, donde Jesuchristo dexó en el paño la semejança siquier ymagen de su faz preciosa, la qual por nuestros tiempos guardan en Roma ${ }^{72}$.

El lector de la Estoria del noble Vespasiano podía ver el proceso de fábrica de un edificio dedicado a la custodia de una de las reliquias más famosas de la cristiandad, por otro lado consignada en las guías de peregrinación. Realidad (existencia de la Santa Faz - con independencia de su tradición legendaria-) y ficción se interrelacionaban, pero la construcción de la iglesia (grabado 6) adquiere plenitud de sentido en contraposición con otras imágenes de destrucción de la obra, la núm. 4, derribo de Jafa, pero especialmente la núm. 12, la destrucción de Jerusalén (grabado 7). En todos los casos se visualizan diferentes fases del proceso, constructivo y destructivo, en los tres está presente Vespasiano, con su corona identificativa, en uno, núm. 4, a caballo y en los otros dos a pie, con la diferencia sustancial de que los operarios encargados de los trabajos materiales han cambiado sus instrumentos de trabajo: en estos últimos casos están utilizando unas piquetas destructivas.

La recepción de la Estoria del noble Vespasiano no la debemos desligar de las imágenes que lo acompañan, tanto en las ediciones de Sevilla (1499) como en la de Lisboa (1496), dependientes de un arquetipo común, pero también diferentes en su número, estética y poética. Del mismo modo tampoco podemos olvidarnos de que en la época se suscitaron numerosas polémicas sobre el empleo de las imágenes, a lo que no eran ajenas los conflictos religiosos contra musulmanes y contra judíos, aspecto muy bien estudiado por

\footnotetext{
${ }^{71}$ Gerhard Wolf, art. cit., p. 106.

${ }^{72}$ Bernardo de Breidenbach, ob. cit., p. 108 y 192, respectivamente.
} 
Felipe Pereda y que hemos dejado para otra ocasión. Las quince xilografías sevillanas implican, por un lado, una selección de los episodios ilustrados, sin que pretendan trasladar el texto a la imagen, sino representar de forma significativa la escena elegida. Como otras del texto, las relativas a la curación de Vespasiano fijan en la memoria más fácilmente los episodios recreados, en algún caso rememorativo del Via crucis, al tiempo que resaltan el poder curativo de la imagen de Cristo y del bautismo. El personaje de Verónica y la Santa Faz alcanzaron cada vez mayor popularidad, y el poseedor de la novelita podía disponer en su recepción privada, íntima, de una xilografía con el famoso paño. Con las consiguientes y adecuadas oraciones a través de estampas similares se llegaban a obtener indulgencias. Sea como fuere, el grabado también potenciaba la afectividad, la empatía del receptor, en los tiempos de la llamada devotio moderna, en los que se había revitalizado el personaje.

Desde el plano sintagmático, la sucesión de imágenes destaca los resultados de varias técnicas usadas en el texto, sobre todo el paralelismo y el contraste en los casos analizados. La imagen concentra varios significados en sus signos visuales y al reiterar personajes, gestos, actividades y objetos, favorece la relación entre unas y otras (curación de Vespasiano y bautismo; desplazamiento marítimos de búsqueda y de castigos). Las estampas recalcan los paralelismos y contrastes existentes en el texto, al que refuerzan notoriamente, de modo que nos dan unas pautas objetivas de cómo deseaban los editores que se recibiera el texto. En otros casos (construcción de la Iglesia y destrucción de Jerusalén) se imponen unos nuevos sentidos. Desde esta óptica, su empleo va más allá del valor ilustrativo, embellecedor, placentero o rememorativo. En síntesis, resaltan por sí y por contraste los efectos curativos, beneficiosos, de estar con Jesucristo o los destructivos de ir en su contra. Refuerzan determinadas tesis político-religiosas, fácilmente interpretables en la España de fines del siglo xv, en consonancia con la propaganda antisemita emanadas desde los círculos del poder. La obra ofrecía los modelos para la recuperación de males incurables como la lepra (la adoración y el contacto con la efigie de Jesucristo y el bautismo). Teniendo en cuenta que en la España de la época los judíos eran equiparados a esta enfermedad, las consecuencias eran fácilmente identificables con su extirpación (expulsión de 1492) o curación (bautismo). Un viejo texto de raíz antisemita recobraba nueva actualidad, como había sucedido en épocas anteriores.

Recibido: 23/04/2016 Aceptado: 27/06/2016 


\section{$\cos$}

TeXto e imagen en la Estoria Del noble Vespasiano (SEVILla, 1499):

LA CURACIÓN DEL EMPERADOR

RESUMEN: En el artículo se estudia la relación entre texto e imagen en el incunable de la Estoria del noble Vespasiano (Sevilla, 1499). De las 15 xilografías de la obra, se analizan solo los relativas a la curación del emperador, en las que la Verónica desempeña un papel fundamental. Las imágenes adquieren plenitud de sentido en relación con el texto que embellecen, con otros grabados de la obra y con el contexto de su impresión, en clave político religiosa y antisemita.

Palabras ClaVe: Destrucción de Jerusalén. Vespasiano. Lepra. Verónica. Expulsión de los judíos.

\section{TeXt and Image in the Estoria Del noble Vespasiano (SeVIlle, 1499):} THE HEALING OF THE EMPEROR

ABSTRACT: In the article is studied the relationship between text and image in the incunabula of the Estoria del noble Vespasiano (Seville, 1499). Of the 15 woodcuts of the work, they analyzed only on healing the emperor, in which Veronica plays a fundamental role. Images acquire full meaning in relation to the text embellishing with other engravings of the work and the context of printing in key religious political and anti-Semitic.

Keywords: Destruction of Jerusalem. Vespasian. Leprosy. Veronica. Expulsion of the jews. 